\title{
An Efficiency Analysis of Conventional and Islamic Banking in Pakistan
}

\author{
${ }^{a}$ Hina Ali, ${ }^{b}$ Hafiza Hina Saleem, ${ }^{c}$ Kalsoom Paracha, ${ }^{d}$ Sabiha Abdul Quddus \\ ${ }^{a}$ Assistant Professor, Department of Economics, The Women University Multan, Pakistan. \\ Email: hinaali@wum.edu.pk \\ ${ }^{\mathrm{b}}$ MPhil Scholar, Department of Economics, The Women University Multan, Pakistan. \\ ${ }^{c}$ Assistant Professor, Department of Islamic Studies and Comparative Religions, The Women University Multan, \\ Pakistan. \\ ${ }^{\mathrm{d}}$ Lecturer, Department of Islamic Studies and Comparative Religions, The Women University Multan, Pakistan
}

\begin{tabular}{l}
\hline ARTICLE DETAILS \\
\hline History: \\
Accepted 15 May 2021 \\
Available Online June 2021 \\
\hline Keywords: \\
Islamic Banking, Growth Rate, \\
Conventional Banking, ARDL, \\
Pakistan \\
JEL Classification: \\
G21, C87 \\
\hline
\end{tabular}

DOI: $10.47067 /$ real.v4i2.161

\begin{abstract}
The current estimation is involved to regulate the efficiency analysis between Islamic banking and conventional banking by reference to GDP growth, total reserve as dependent variables, and total assets, total deposits, total investment, and total liabilities as autonomous variables. Time series data is collected from 1990 to 2019, Islamic banking has increased facts and lending in Pakistan. Most people believe in Islamic banking philosophy as it is Islamic shariah based with full reserves, total assets, total deposits, total investment, and total liabilities, Considered the descriptive variables independent variable in which the coefficient of the total assets, the total deposit had a highly significant impact on GDP growth rate. Pakistan had a dynamic role regarding the banking sector when assets of the banking sector increases and GDP Growth also increased in Pakistan. Autoregressive lagged estimation model and economic effectiveness on the supply side and Islamic banking relationship in Pakistan, GDP growth is positive and significant
\end{abstract}

(C) 2021 The authors. Published by SPCRD Global Publishing. This is an open access article under the Creative Commons AttributionNonCommercial 4.0

Corresponding author's email address: hinaali@wum.edu.pk

\section{Introduction}

This study, investigation research a historic background of Pakistani banking meanwhile its freedom from British people rules on August 14, 1947. It titles the journey of the Islamic Republic of Pakistan banking sector from the establishment of SBP on July 1, 1948, as the leading bank. Bank was defined as the business drive of enduring and protection of money owned by other entities and objects and then lending out this money to behavior economic actions such as creation profit operational expenditures. Islamic banking was famed at the national level in Pakistan. The government was preparing the fluctuations strategies of banks. Though; in Pakistan around gathering for the application process of Islamic banking. The purpose of the council is to abolish the interest system in the Pakistan economy. 
In Arabic linguistic Reba is a substitute time of interest they are work in conventional banking procedures. Reba income indicting planned further amount on a loan long based on the extent of the credit period. Stages for Islamic banking and monetary arrangement in Pakistan were continuing in 1977-78. Pakistan was among the three states in the world that had been exasperating to accomplish interest-free banking at an all-inclusive level the procedure of Islamic financing ongoing with the improvements in particular financial organizations with Islamic principles. all conventional lending acts were complete interest-free about 7,000 interest-free inductees were unlocked at all the national commercial bank's assembly. Pakistan's first government in the Muslim world started with Islamic banking on January 1, 1980 (Qureshi \& Shaikh, 2012).

The Islamic banking system, that when this perception comes similar and smaller people are willing to receive but after investment, system implements and works efficiently, people become cognizant of this arrangement. There is always an encounter to change, but when change has happened in any field, this produces a lot of developments in this field. The dissimilarity between Islamic and conventional banks is owing to their properties. They have instigated that around is no interconnection between Islamic bank funding and economic development in the short run. But they have originated that the Islamic bank investment stimulates the fixed speculation level positively (Akram, Rafique \& Alam, 2011).

In Pakistan, Islamic banking manufacturing has now grownup to more than 16 percentage of the overall banking sector and a role of the monetary sector in the economic development of any country, covid-19 predicament willpower arise will add to of traditional banking business model revenue compression and low cost-effectiveness snugger guideline after the previous financial crisis and cumulative struggle from tracker sets in addition to new (Rashid \& Riaz, 2018). Muslims believe that justice and impartiality in chance are crucial for a civilization to function. Islamic banks recognized a zakat fund for collecting money to be designated to religious organizations. The amount is 2.5 percent of assets held by the bank's stockholders. Zakat is also one of the five tents of Islam and Islamic banking that are required to collect zakat from customers' accounts. A shariah board of experts overseas and recommends the ownership of transaction of every Islamic bank, to make sure all activities conform to Islamic principles. in Islamic shariah, the legal code of Islam must be compatible with all transactions' Fiqh- al- muamalat is the rule of governing trade transaction in Islamic banking.

\section{Review of Literature}

Rashid, Hassan, and Ahmad (2009) deliberate that examine belongings factors which remained answerable to defiance of the clienteles to Islamic banking. The obtained data were subjected to Correlation and regression test were practical and findings revealed that cost-efficiency. Formation to used had a great impact on purchaser confidence than other characters like spiritual compliance and community influence unpredictability of the interest-based economic system. the communications are Reba free and avoid immoral observes, contribute the enthusiastically to achieve purposes of Islamic Economy conventional banks was effective on the imitation philosophies anywhere the programmed interest rate was core activity. Khattak (2010) awareness of Islamic banks remained not innovative Islamic banking was very effortlessly receiving acknowledgment in the financial market. the conventional banking industry was a well-established rival for Islamic banking industry IBI must deliberate their consumer's scheme, contentment, and receptiveness level near the patron's gratification awareness level towards the IBI that examines affiliation amidst different demographic variables and fulfillment consciousness of customs. A model of 156 defendants from changed metropolises of Pakistan was nominated one way ANOVA was to the checkered connection amongst demographic variables and gratification responsiveness. 
Imam and Kpodar and Kramarenko (2010) studied inspected the determinants of the proposal of Islamic bank dissemination everywhere in the world. The development of Islamic banking was accompanying to income per capita, percentage of Muslims people a state status as an oil trendy, as per was pecuniary accumulation by nations intimacy to Islamic monetary centers in central-eastern. the implicit had Interest rates negative impact on Islamic banking. The superiority of administrations does not substance, doubtless as the often-higher obstacle by Shariah law outdoes the quality of local foundations in utmost republics.

Ansari and Rehman (2011) estimated that the banking system in Pakistan is prosperous these existences of conventional investment were in repetition in Pakistan that was meanwhile longtime and mainstream of the present trades are complicated. As Muslim numerous people prepare not to trust on the conventional banking system, they do not usage lending services to evade from on the additional lateral people believed in Islamic banking free interest consideration they can use their services can be offered they can get involved into banks. To quantify the financial performance of the banking industries, Return on Assets (ROA) used as active as a substitution and that was measured together with other illustrative variables to measure the impact of descriptive factors, Descriptive Statistics, Correlation Matrix, and F-Statistics are used to analyze the influence of explanatory variables.

Jaffar and Manarvi (2011) deliberately surveyed the performance of Islamic and conventional banks operating in Pakistan from 2005 to 2009 investigated CAMEL test normal aspects. financial data for the study was excavated from the bank's pecuniary announcements prevailing on the state bank of Pakistan site. CAMEL test which was an average test to checkered strength of monetarist institutions was rummage-sale to regulate the presentation of Islamic and conventional banks. Islamic banks accomplished better in predisposed acceptable capital and better liquidness location whereas commercial banks established in administration superiority and receiving ability. Qureshi and shaikh (2012) observed the proportionate efficiency of the banking system in Pakistan encompassing Islamic banks (IB) central banks with Islamic banking partition (IBD) and commercials banks (CB). We are analyzed cost, profits, and revenue effectiveness data envelopment analysis (DEA), virtual analysis of banks' practical, pure procedural and rule productivities. We used the proficiency scores of DEA to investigate the impact of productivity. Islamic banks would be stimulated effectual border in banking trade. Mostly, there two conducts to learning banking effectiveness; outdated financial ratios and nonparametric approaches efficiency of conservative banks in Pakistan designate no enhancement phase.

Zaheer, Onega, and wintergreen (2012) inspect the changes in groups rejoinders to financial policy shudders transversely bank size, fluidness, traditionalist versus Islamic in Pakistan in disparity, great banks continue their progressing nonetheless of their liquidness positions. Investors in Islamic banks are, for all applied resolutions, stakeholders to receive there no assurance by esteem to face worth of their deposits. In code, individuals share equally in the profits and losses of earning of the bank Where they have accounts. Correspondingly, to advantage funded household consumption, Islamic banks establish an arrangement of suspended auctions, effective occupancies, and profit and loss distribution preparations to investment domiciliary.

Islam and Amir (2016) investigate knowledge categories of flexibility complications in Islamic banking to scrutinized the explanations of runniness difficulties laterally their impressions on the Islamic banking industry learn to fluidness difficulties Islamic banking industry (IBI). With learned enterprise was constructed in primary research which was carried out through expansion of a survey with consultations of Islamic law consultants. The survey was distributed between Islamic investors promised in the liquidness administration process. The originally surveyed liquidness complications 
used by the Islamic banking industry to control them. premeditated decorated shortages in bank observe of Shariah-compliant extenuation tools.

Yildirim (2017) studied investigate was studied Six rapid growth markets (QISMUT) as summarized from Qatar, Indonesia, Saudi Arabia, Malaysia, UAE, and Turkey) determination plays an imperative protagonist in the globalization of Islamic banking manufacturing. Data Envelopment Analysis (DEA) was used in the effectiveness of dimensions whereas the Malmquist Total Factor Efficiency Catalogue was rummage-sale to quantity the total aspect productivity change. QISMUT Islamic banks encounter that used the technical productivity.

Rashid et al. (2018) learned subsidizes empirical prose on Islamic economics by responsibility judgment of Islamic and conventional banking in Pakistan concluded period 2005-2014 that applied together non-parametric and parametric cataloging approaches to explore whether pecuniary proportions used to differentiate among Islamic and conventional banks analyzed discloses Islamic banks are less gainful, healthier oppressed, more fluid, and short level risk of credit as equated to conventional complements the unpredictability level fewer proceeds of Islamic banks as likened their contestants. quantified those spiritual opinions performance a contributory character in Islamic banks as clienteles incline to pay additional devotion Islamic banks

\section{Data and Methodology}

In data and methodology clarified that A time-series data on GDP growth, overall reserves occupied as reliant variables and total assets, total deposits, total investment, and total liabilities as an independent variables' exertion had been investigated in order to understand the effectiveness of conventional and Islamic banking in Pakistan. The globe development indicator has taken GDP growth rate and total reserve data from (WDI), For conventional banking all of these data variables were in trillions. From 1990 to 2019, we have used these time series data. Data collected from 2003-2004 fiscal year of the central bank of Pakistan were in the trillions and percentage of that collected 30 June annual report of SBP, and estimated analyses of dependent and independent variables demonstrate economic efficiency by using the ARDL approach, long run, short-run integration analysis, negligent economic impact, and EViews 11 estimated results source.

In research, an object that you need to enumerate basically refers to a to individual, dwelling, object. The casual way of sympathetic the difference between a dependent variable and an independent variable is to see what is the mean of the variable relations. A descriptive association of variables between a series of express values, with a condition that each discrete being has a descriptive value. After collecting the variables required, the variables to address the economic performance are very significant to be distinct. GDP growth rate and total reserve in this inspection are variables dependent and all other variables are described independently. 
Table 1: List of Variables and their Expected Sign in Growth

\begin{tabular}{|c|c|c|c|c|}
\hline $\begin{array}{l}\text { Dependent } \\
\text { Variables }\end{array}$ & $\begin{array}{l}\text { Descriptive } \\
\text { Variables }\end{array}$ & Unit of Measurement & Source & Sign \\
\hline GDPD & GDP Growth rate & Billions & $\begin{array}{l}\text { World } \\
\text { Development } \\
\text { Indicator }\end{array}$ & + ive \\
\hline TRESRV & Total Reserve & Billions & $\begin{array}{l}\text { World } \\
\text { Development } \\
\text { Indicator }\end{array}$ & + ive \\
\hline \multicolumn{5}{|l|}{$\begin{array}{l}\text { Independent } \\
\text { Variables }\end{array}$} \\
\hline T Ass & Total Assets & millions and billions & $\begin{array}{l}\text { state bank of } \\
\text { Pakistan }\end{array}$ & +ive \\
\hline T Dep & Total Deposit & millions and billions & $\begin{array}{l}\text { state bank of } \\
\text { Pakistan }\end{array}$ & +ive \\
\hline $\mathrm{T} \mathrm{I}$ & Total Investment & millions and billions & $\begin{array}{l}\text { state bank of } \\
\text { Pakistan }\end{array}$ & + ive \\
\hline Total Lib & Total Liabilities & millions and billions & $\begin{array}{l}\text { state bank of } \\
\text { Pakistan }\end{array}$ & +ive \\
\hline
\end{tabular}

\subsection{Model Specification}

Two different models of banking are conventional banking and Islamic banking. The efficiency analysis between conventional and Islamic banking will be monitored in model specification. The impact of these variables on the effectiveness of trading operations of the bank.

\subsubsection{Conventional banking model}

$$
\begin{gathered}
\text { GDPG }=f\left(\text { T Ass } \text { cb }_{+} \text {T Dep cb }+ \text { T I cb }+ \text { TLib cb }\right) \\
\text { GDPG }=\beta_{0}+\beta_{1}(\text { TA cb })+\beta_{2}(\text { TD cb })+\beta_{3}(T \text { Icb })+\beta_{4}(\text { TL cb })+\mu_{t}
\end{gathered}
$$

Where $\beta$ show the Intercept, $\beta_{o}$ expression Slope of the coefficient, GDPG that means GDP growth rate is dependent variable, T Ass (cb) is the total assets of conventional banking dep (cb) is the total deposit of conventional banking), $\mathrm{T}$ I (cb) of means total investment of conventional banking, $\mathrm{T}$ lib (cb) show the total liabilities are independent variables of conventional banking, $\mu$ means Error term 


$$
\begin{gathered}
R=f(T \text { Ass cb }+ \text { T Dep cb }+ \text { T I cb }+ \text { TLib cb }) \\
R=\beta_{0}+\beta_{1}(T A c b)+\beta_{2}(\text { TD cb })+\beta_{3}(T \text { Icb })+\beta_{4}(T L c b)+\mu_{t}
\end{gathered}
$$

Where $\beta$ show the Intercept, $\beta_{o}$ expression Slope of the coefficient, $\mathrm{R}$ that means Reserve is show in this equation as a dependent variable in conventional banking model, $\mathrm{T}$ Ass (cb) is the total assets of conventional banking dep (cb) is the total deposit of conventional banking), $\mathrm{T} \mathrm{I}(\mathrm{cb})$ of means total investment of conventional banking, $\mathrm{T}$ lib (cb) show the total liabilities of conventional banking, $\mu$ means Error term

\subsubsection{Islamic banking model}

$$
\begin{gathered}
\text { GDPG }=f(\text { T Ass ib }+ \text { T Dep ib }+ \text { T I ib }+ \text { TL ib }) \\
\text { GDPG }=\beta_{0}+\beta_{1}(\text { TA ib })+\beta_{2}(\text { TD ib })+\beta_{3}(\text { T Iib })+\beta_{4}(\text { TL ib })+\mu_{t}
\end{gathered}
$$

Where $\beta$ show the Intercept, $\beta_{o}$ expression Slope of the coefficient, GDPG that means GDP growth rate is the dependent variable in Islamic banking model, $\mathrm{T}$ Ass (ib) is the total assets of Islamic banking dep (ib) is the total deposit of Islamic banking, $\mathrm{T}$ I (ib) of means a total investment of Islamic banking, T lib (ib) and total liabilities are independent variables of Islamic banking, $\mu$ means Error term

$$
\begin{gathered}
\mathrm{R}=\mathrm{f}\left(\mathrm{T} \text { Ass ib }{ }_{+} \text {T Dep ib }+\mathrm{T} \mathrm{I} \mathrm{ib}+\mathrm{TL} \text { ib }\right) \\
\mathrm{R}=\beta_{0}+\beta_{1}(\mathrm{TA} \text { ib })+\beta_{2}(\mathrm{TD} \text { ib })+\beta_{3}(\mathrm{~T} \mathrm{Iib})+\beta_{4}(\mathrm{TL} \text { ib })+\mu_{\mathrm{t}}
\end{gathered}
$$

Where $\beta$ show the Intercept, $\beta_{o}$ expression Slope of the coefficient, $\mathrm{R}$ means Reserve is the dependent variable in Islamic banking model, T Ass (ib) is the total assets of Islamic banking dep (ib) is the total deposit of Islamic banking, T I (ib) of means a total investment of Islamic banking, T lib (ib) and total liabilities are independent variables of Islamic banking, $\mu$ means Error term.

\section{Analysis and Results}

An important part of the analysis is descriptive analysis in this phase for statistical analysis provides you with an impression of your data movements, helps you with an impression of your data movements, helps you to distinguish between outliers and errors and detects interconnected variables. The data were applied between 1990 to 2019, all the data variables used in this study include mean, median, normal skewness and kurtosis. Descriptive analysis results of conventional banking model one and Islamic banking model two show with one table below. 
Table 2: Descriptive Analysis Results of Model 1 and Model 2

\begin{tabular}{|l|c|c|c|c|c|c|c|c|}
\hline \multicolumn{5}{|c}{ Conventional Banking (Model 1) } & \multicolumn{4}{c|}{ Islamic Banking (Model 2) } \\
\hline Variables & Mean & St. Dev & $\begin{array}{c}\text { Skewnes } \\
\text { s }\end{array}$ & $\begin{array}{c}\text { Kurtosi } \\
\text { s }\end{array}$ & Mean & St. Dev & $\begin{array}{c}\text { Skewnes } \\
\text { s }\end{array}$ & Kurtosis \\
\hline GDP & $1.71 \mathrm{E}+10$ & $2.65 \mathrm{E}+10$ & 1.3222 & 2.2317 & 1.8674 & 1.7126 & -0.4378 & 1.8111 \\
\hline $\begin{array}{l}\text { Total } \\
\text { Reserve }\end{array}$ & $9.46+10$ & $1.20 \mathrm{E}+11$ & 0.8445 & 1.7245 & $1.48 \mathrm{E}+10$ & $\begin{array}{c}4.01 \mathrm{E}+\mathrm{O} \\
9\end{array}$ & -0.0312 & 2.3039 \\
\hline $\begin{array}{l}\text { Total } \\
\text { Assets }\end{array}$ & $7.03 \mathrm{E}+\mathrm{og}$ & $9.95 \mathrm{E}+\mathrm{og}$ & 2.5922 & 2.3319 & $1.99 \mathrm{E}+11$ & $6.67 \mathrm{E}+11$ & 3.3621 & 12.5621 \\
\hline $\begin{array}{l}\text { Total } \\
\text { Deposit }\end{array}$ & $9.09 \mathrm{E}+10$ & $1.21 \mathrm{E}+11$ & 0.8961 & 9.1218 & $1.63 \mathrm{E}+11$ & $5.22 \mathrm{E}+11$ & 3.3617 & 12.5606 \\
\hline $\begin{array}{l}\text { Total } \\
\text { Investmen } \\
\mathrm{t}\end{array}$ & $\begin{array}{c}8.92 \mathrm{E}+\mathrm{O} \\
9\end{array}$ & $\begin{array}{c}6.83 \mathrm{E}+\mathrm{O} \\
9\end{array}$ & 0.3087 & 2.2957 & $\begin{array}{c}8.59 \mathrm{E}+1 \\
\mathrm{o}\end{array}$ & 3.36174 & 2.1569 & 5.7533 \\
\hline $\begin{array}{l}\text { Total } \\
\text { Liabilities }\end{array}$ & 1.5656 & 1.8217 & 0.0879 & 3.3192 & $1.63 \mathrm{E}+11$ & 12.5606 & 3.3617 & 12.5606 \\
\hline
\end{tabular}

Note: Estimated results Source EViews 11

First of all, we examined the data obtainable the descriptive statistic that includes Standard deviation, Skewness, and Kurtosis for purpose of showing findings of model 1 conventional banking. The GDP has $1.71 \mathrm{E}+10$ average values are $2.56 \mathrm{E}+10$ of volatility about mean value. The total reserve has $9 \cdot 46+10$ mean values with a 1.20E+11 standard deviation. total assets have a 7.03E+o9 mean value with the $9.95 \mathrm{E}+\mathrm{Og}$ variability about mean. The total deposit has a 9.09E+o9 mean value of $1.20 \mathrm{E}+11$ disparity about means and the total investment has an $8.92 \mathrm{E}+09$ average value with a $6.83 \mathrm{E}+09$ distinction about mean and total liabilities has 1.565699 average value with 1.821701 .

To grade the skewness consequences, the values must be range from -0.5 to 0.5 , data should be fairly symmetrical. Subsequently, the Skewness value of the total investment and total liabilities value 0.087991 showed that data was fairly symmetrical skewness. Total assets skewness value 2.592292 and GDP growth value 1.322256 are highly skewed because their values are less than-1 or greater than 1 . Total deposit skewness value 0.8961 and total reserve value are 0.8445 moderately skewed because their values between range -1 and -0.5 or between 0.5 and 1 , so data values are moderately Skewed. To dimension the kurtosis results, GDP growth total reserve, total deposit, total investment less in the tails normal distribution. Because if kurtosis value less than 3, then dataset had light tails then standard distribution less in decisions. Total assets values and total liabilities value more in the tail's normal distribution Because if the kurtosis value larger than 3, then the dataset has weightier tails than a normal circulation more in the tails.

In model 2 Islamic banking Estimation Mean values of GDP growth, total reserve, total assets, total deposit, total investment, and total liabilities show the average variation in St. Dev, In skewness that to grade the skewness consequences, the values must be range - 0.5 to 0.5 , data should be fairly symmetrical. Subsequently, the Skewness value of GDP growth and that of total reserve value showed that data was fairly symmetrical skewness. Total assets, total deposit, total investment, and total 
liabilities are highly skewed because their values are less than-1 or greater than 1.

To dimension the kurtosis results, GDP growth total reserve less in the tails normal distribution. Because if kurtosis value less than 3, then dataset had light tails then standard distribution less in decisions. Total assets, total liabilities, total deposit, and total investment value more in the tail's normal distribution Because if the kurtosis value larger than 3, then the dataset has weightier tails than a

normal circulation

more

in

the

tails. 


\section{Table 3: Correlation Analysis of Variable}

\begin{tabular}{|c|c|c|c|c|c|c|c|c|c|c|c|c|}
\hline \multicolumn{7}{|c|}{ Correlation Matrix (CB Model 1) } & \multicolumn{6}{|c|}{ Correlation Matrix (IB Model 2) } \\
\hline Variables & $\begin{array}{l}\text { GDP } \\
\text { Gr. }\end{array}$ & $\begin{array}{c}\text { Total } \\
\text { Reserve }\end{array}$ & $\begin{array}{l}\text { Total } \\
\text { Assets }\end{array}$ & $\begin{array}{c}\text { Total } \\
\text { Deposit }\end{array}$ & $\begin{array}{c}\text { Total } \\
\text { Investment }\end{array}$ & $\begin{array}{c}\text { Total } \\
\text { Liabilities }\end{array}$ & $\begin{array}{c}\text { GDP } \\
\text { growth }\end{array}$ & $\begin{array}{c}\text { Total } \\
\text { Reserve }\end{array}$ & $\begin{array}{c}\text { Total } \\
\text { Assets }\end{array}$ & $\begin{array}{c}\text { Total } \\
\text { Deposit }\end{array}$ & $\begin{array}{c}\text { Total } \\
\text { Investment }\end{array}$ & $\begin{array}{c}\text { Total } \\
\text { Liabilities }\end{array}$ \\
\hline $\begin{array}{c}\text { GDP } \\
\text { growth }\end{array}$ & 1 & & & & & & 1 & & & & & \\
\hline $\begin{array}{c}\text { Total } \\
\text { reserve }\end{array}$ & 0.198 & 1 & & & & & 0.022 & 1 & & & & \\
\hline $\begin{array}{c}\text { Total } \\
\text { Assets } \\
\end{array}$ & -0.24 & -0.75 & 1 & & & & 0.2596 & -0.169 & 1 & & & \\
\hline $\begin{array}{c}\text { Total } \\
\text { Deposit }\end{array}$ & -0.18 & -0.53 & 0.786 & 1 & & & 0.3645 & 0.274 & 0.6129 & 1 & & \\
\hline $\begin{array}{c}\text { Total } \\
\text { Investment }\end{array}$ & -0.26 & -0.8 & 0.98 & 0.762 & 1 & & 0.2596 & -0.169 & 1 & 0.6129 & 1 & \\
\hline $\begin{array}{c}\text { Total } \\
\text { Liabilities }\end{array}$ & -0.28 & -0.79 & 0.967 & 0.7815 & 0.9946 & 1 & 0.2581 & -0.169 & 0.9999 & 0.613 & 0.99999 & 1 \\
\hline
\end{tabular}


Initially, to ration the correlation matrix validates the GDP growth are powerfully connected with total reserve, total assets, total deposit, total investment, and total liabilities are strongly correlated with GDP, the total reserve is the weak correlation with total assets, total deposit, total investment, and liabilities because is coefficient between -0.3 and 0.3 so its feeble correlation. The finding expression that the correlation matrix validates total reserve is the moderate correlation with total assets, total deposit, total investment, and total liabilities. correlation matrix accompanying the Total assets are strongly correlated with the total deposit, total investment, and total liabilities because it's coefficient superior then +0.7 so, it's strongly correlated, the total deposit is a strong positive relationship with total investment and total liabilities, total investment strongly linked with total liabilities and total liabilities are perfect positive affiliation.

Results of Islamic banking the correlation matrix validates the GDP growth are weakly correlated with total reserve, total assets, total deposit, total investment, and total liabilities are moderate with GDP, the total reserve is the weak correlation with total assets, total deposit, total investment, and liabilities as a coefficient between -0.3 and 0.3 so its weak correlation matrix associated the Total assets are strongly correlated with the total deposit, and total liabilities because its coefficient greater then +0.7 so, it's strongly correlated, total assets are moderate correlation with total investment because its values between +0.3 to +0.7 . total deposit is a strongly positive relationship with total liabilities moderate correlation with total investment because its values between +0.3 to +0.7 . total investment strongly linked with total liabilities and total liabilities are perfect positive.

Table 4: Short Run Estimations of ARDL Models

\begin{tabular}{|c|c|c|}
\hline Variables & Model 1 & Model 2 \\
\hline & $\begin{array}{l}\text { Conventional Banking Model } \\
\text { ARDL }(1,0,0,0)\end{array}$ & $\begin{array}{l}\text { Islamic Banking Model } \\
\operatorname{ARDL}(1,0,0,1)\end{array}$ \\
\hline \multirow{2}{*}{$\mathrm{C}$} & $7.20 \mathrm{E}+09$ & $1.48 \mathrm{E}+10$ \\
\hline & 0.0000 & 0.0000 \\
\hline \multirow{2}{*}{ Total Reserve (-1) } & -0.468207 & -1.518886 \\
\hline & 0.0046 & 0.0148 \\
\hline \multirow{2}{*}{ Total Libilites } & -0.031552 & $-2.97 E+08$ \\
\hline & 0.0128 & 0.0000 \\
\hline \multirow{2}{*}{ Total Investment } & 0.123892 & $2.19 \mathrm{E}+09$ \\
\hline & 0.2447 & 0.0000 \\
\hline \multirow{2}{*}{ Gdp Growth Rate** } & $-2.56 E+08$ & $-1.78 E+09$ \\
\hline & 0.0000 & 0.0000 \\
\hline
\end{tabular}

Note: Estimated results EViews 11 
In the short-run estimation of conventional banking in model 1 assistance, it assures the looked errors by exploiting the error correction time in the short-run and fastening the long-run linking of variables over the antique $t$ series for long time attachment of variables it also elevations compensating the happened errors. $\mathrm{C}$ measure the which measure the convergence in model and that is positive and consume highly significant probability value that confirms the long-run causality from explanatory variables to be dependent variables. The value of the coefficient is explained very high ranking of significantly towards its efficiency situation.

The first lag of total reserve has a negative coefficient value with significant probability. GDP growth has a negatively coefficient value related to significant probability, Total investment has a positive coefficient with insignificantly probability and Total liabilities has a negative coefficient with significant probability. In Islamic banking model 2 explain the $\mathrm{C}$ which measures the convergence of model positive and $t$ static have highly significantly probability value that approves the long-run causality from explanatory variables to be the dependent variable, value of coefficient explained very high rank of convergence towards its efficiency condition. First lag of total reserve has negative coefficient value with significant probability, total liabilities value of the coefficient is positive and $t$ statistic with a highly significant and first lag of investment value of coefficient negative with $t$ statistic highly probability, total deposit the value of the coefficient is positive with t static highly probability.

Table 5: Long run Estimation of ARDL Models:

\begin{tabular}{|c|c|c|}
\hline & Model 1 & Model 2 \\
\hline Variables & $\begin{array}{c}\text { Conventional Banking } \\
\text { Model }\end{array}$ & Islamic Banking Model \\
\hline & ARDL (1,0,0,0) & $-1.96 \mathrm{E}+08$ \\
\hline Total Liabilities Cb & -0.06739 & 0.7351 \\
\hline Total Investment & 0.0013 & $1.44 \mathrm{E}+09$ \\
\hline & 0.26461 & 0.0677 \\
\hline GDP Growth Rate & 0.2294 & $-1.17 \mathrm{E}+09$ \\
\hline & $-5.47 \mathrm{E}+08$ & 0.0077 \\
\hline C & 0.4785 & $9.71 \mathrm{E}+09$ \\
\hline
\end{tabular}

Note: Estimated result source EViews 11

Long-run consequences of conventional banking model the considered the explanatory variables independent variable in which coefficient of total liabilities and the total investment is a positive and highly significant impact on the GDP Growth rate. When total liabilities increase then the GDP growth rate also increases p-values are less than 0.09 so the probability is significant. So, the banking sector is a positive efficiency influence on the GDP growth rate. 
The value of total liabilities -0.067390 and is positive because the linkage between liabilities and GDPG is positive. The coefficient of investment positive with insignificant probability. Islamic banking model 2 explains the value of the coefficient of liabilities is negative because the linkage between liabilities and investment is negative so they are directly related. In the long run, the value of the coefficient of the total deposit value positive, and probability is significant. Investment has a negative value but a significant probability value.

Table 6: The F-test for Co-integration

\begin{tabular}{|c|c|c|c|c|c|}
\hline \multirow[b]{2}{*}{ Model } & \multirow[b]{2}{*}{ F-Statistic } & \multicolumn{2}{|c|}{$\begin{array}{c}\text { At } \\
5 \% \text { significant Level }\end{array}$} & \multicolumn{2}{|c|}{$\begin{array}{c}\text { At } \\
10 \% \text { significant Level }\end{array}$} \\
\hline & & Lower bound & Upper bound & Lower bound & Upper bound \\
\hline Model 1 & 3.811095 & 2.79 & 3.67 & 2.37 & 3.2 \\
\hline Model 2 & 3.4583121 & 2.79 & 3.67 & 2.37 & 3.2 \\
\hline
\end{tabular}

Note: Estimated Result EViews11

In conventional banking model value of bound test accumulation convention that F-statistic value 3.811095 is and critical bound value at 1 percentage is 4.66 that authorizes that value of F-statistic is the more serious value of upper bound value the deductions expression the long run exists among variable. So, there occurs a long-run suggestion between variables. In the Islamic banking model value of finding bound test results for cointegration that shows that F-statistic is 3.453121 and critical bound value at 1 percentage is 4.66 that verifies that value of F-statistic is the more serious value of upper bound value. the suppositions show long- run exist among the variable.

$$
\mathrm{F}>1(1)
$$

Figure 1: Cumulative Sum of Recursive Residuals and Square of Sum Conventional Banking Model 1

\section{CUSUM Test}

12

8

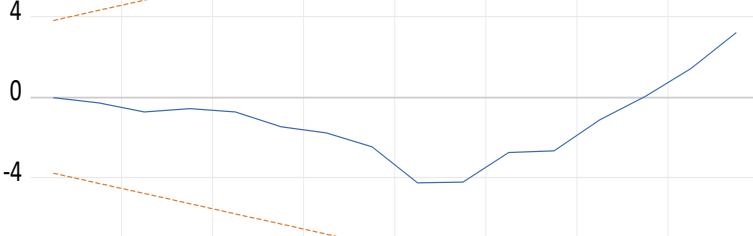

$-8$

$-12$

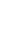

$\begin{array}{llllllll}2004 & 2006 \quad 2008 & 2010 & 2012 & 2014 & 2016 & 2018\end{array}$
CUSUMQ Test

12

8

4

0

$-4$

$-8$

$-12$

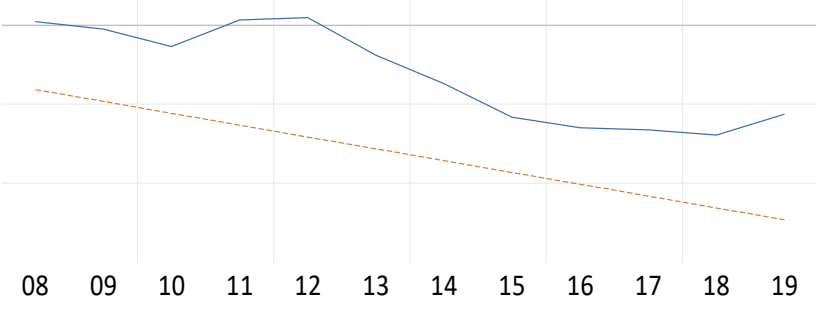

_ CUSUM _-_._. $5 \%$ Significance 


\section{Figure 2: Cumulative Sum of Recursive Residuals and Square of Sum} Islamic Banking Model 2
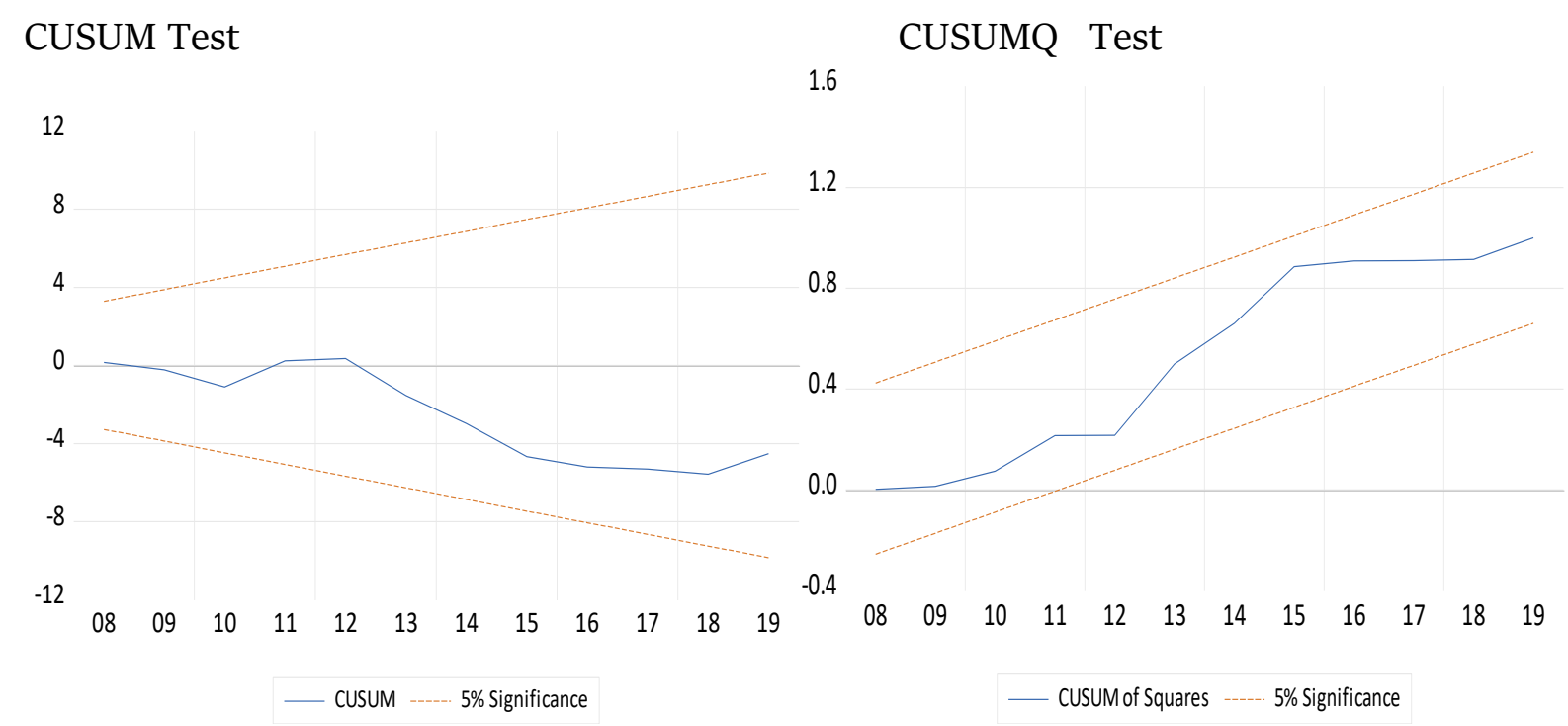

The straight line describes the critical bound at a 5 percent level of significance. This figure is outlined to show the reliability and implication by preceding the square. The blue line in this digit indicates the significance between red lines at the 5-percentage level of significance. The residual sum of the square is discovered to equivalence the outcomes of the Auto Regressive Distributive Lag with another model of Auto Regressive Distributive Lag and estimate the stability of the outcomes.

\section{Conclusion}

The study was developed in Pakistan from 1990 to 2019 for an efficiency test between conventional and Islamic banking. Data from the time series are taken from the conventional banks' annual reports. Most of the data can be found at Pakistan's official state bank of Pakistan and estimated results by using the ARDL approach show the long run, short-run results show impact on efficiency economy. In short-run estimate assistance in assures the looked errors by exploitation the error correction time in short-run and fastening the long-run linking of variables over the antique t series for long time attachment of variables it also elevates compensating the happened errors. The value of the coefficient is explained very high ranking of significantly towards its efficiency situation.

In the long run conventional banking model, the banking sector is positively influencing GDP growth. The total liability value is good because the connection between liabilities and GDPG is good. In addition, the GDP growth rates increase p-values when total liabilities increase also less than o.09. In the short-run Islamic banking model, $\mathrm{C}$, which measures the convergence between the positive and $\mathrm{t}$ static model, has an extremely significant probability value, which approves that the long-lasting causality from explained variables is the dependent variable. In long-run estimation, the value and probability of the coefficient of the total deposit value are substantial. Investment has a negative value but an important long-term probability value. In the short term, however, the value of the investment is negative, because it has a negative connection between liabilities and investment.

\section{Policy Implication}

To keep abreast of international Islamic banking growth, Pakistan must rethink its existing policies and principles. The government would revitalize and sustain more Islamic commercial institutions such as banks, Islamic windows, and Islamic rural banks. The government would also 
inspire Islamic banks in Pakistan to open up more branches.

- Govt should enthuse the Islamic banking system and instrument announcement rendering to Islamic shariah in Pakistan.

- The country should attention to economic and monetary policies proficiently. still, constancy of the government must be obligatory for the progress

- Government should stimulate the banking sector to grow the level of investment in the country. Some appropriate happenings have been taken by the administration for economic growth and unconditionally performance of fiscal financial approach in the country.

- Compared to conventional banking in Pakistan, the Islamic banking system is dispersing at a high rate. The Islamic banking system will grow further, the people of Pakistan and still different countries around the world believe that the Islamic Banking system is the same as conventional, the dissimilarity is a name and nothing else. The strategy-make awareness of Islamic banking policies should give more significance to consciousness

\section{References}

Akram, M., Rafique, M., \& Alam, H. M. (2011). Prospects of Islamic banking: reflections from Pakistan. Australian Journal of Business and Management Research, 1(2), 125

Ansari, S., \& Rehman, K. U. (2011, November). Comparative financial performance of existing Islamic Banks and contemporary conventional banks in Pakistan. In 2nd International Conference on Economics, Business and Management, IACSIT Press, Singapore (pp. 25-26

Imam, P. A., Kpodar, K. R., \& Kramarenko, V. (2010). Islamic banking: how has it diffused? IMF Working Papers, 2010(195).

Islam, A., \& Amir, S. (2016). Liquidity problems in Islamic banks; Reasons, impacts and solutions.

Jaffar, M., \& Manarvi, I. (2011). Performance comparison of Islamic and Conventional banks in Pakistan. Global journal of management and business research, 11(1).

Khattak, N. A. (2010). Customer satisfaction and awareness of the Islamic banking system in Pakistan. African Journal of Business Management, 4(5), 662-671.

Qureshi, M. A., \& Shaikh, M. (2012). The efficiency of Islamic and conventional banks in Pakistan: a non-parametric approach. International Journal of Business and Management, 7(7), 40.

Rashid, A., \& Riaz, M. (2018). Are Islamic banks different from conventional banks? An investigation using classification techniques. Journal of Islamic Business and Management, 8(1).

Rashid, M., Hassan, M. K., \& Ahmad, A. U. F. (2009). Quality perception of the customers towards domestic Islamic banks in Bangladesh. Journal of Islamic Economics, Banking and Finance, 5(1), 109-131.

Yildirim, İ. (2017). Financial efficiency analysis of Islamic banks in the QISMUT countries.

Zaheer, S., Onega, S., \& Van Wijnbergen, S. (2012). The transmission of monetary policy through conventional and Islamic banks. 